OPEN ACCESS

Edited by:

Hai Xu,

Tianjin University, China

Reviewed by:

Liping Zhu,

Chinese Academy of Sciences, China

Hao Long,

Chinese Academy of Sciences, China

*Correspondence:

Steffen Mischke

smi@hi.is

Specialty section:

This article was submitted to

Quaternary Science, Geomorphology

and Paleoenvironment,

a section of the journal

Frontiers in Earth Science

Received: 11 April 2020

Accepted: 26 May 2020

Published: 17 June 2020

Citation:

Mischke S, Lee MK and Lee Y (2020) Climate History of Southern Mongolia Since $17 \mathrm{ka}$ : The Ostracod, Gastropod and Charophyte Record

From Lake Ulaan.

Front. Earth Sci. 8:221. doi: 10.3389/feart.2020.00221

\section{Climate History of Southern Mongolia Since 17 ka: The Ostracod, Gastropod and Charophyte Record From Lake Ulaan}

\author{
Steffen Mischke ${ }^{1 *}$, Min Kyung Lee ${ }^{2}$ and Yong II Lee ${ }^{3}$ \\ ${ }^{1}$ Institute of Earth Sciences, University of Iceland, Reykjavik, Iceland, ${ }^{2}$ Korea Polar Research Institute, Incheon, South Korea, \\ ${ }^{3}$ School of Earth and Environmental Sciences, Seoul National University, Seoul, South Korea
}

Late glacial and Holocene environmental and climate change in the Gobi Desert is poorly understood due to the lack of appropriate geological archives and commonly faced difficulties in establishing reliable chronologies. Here, the relatively well-dated sediment record from the terminal Lake Ulaan (Ulaan Nuur) is used to reconstruct the lake history and climate in the region. Most abundant calcareous fossils in the lake sediments are ostracod (micro-crustacean) valves. The ostracod assemblage is dominated by Limnocythere inopinata, and generally very shallow conditions and sodium-dominated waters are inferred for Lake Ulaan. A single period of significantly increased silt accumulation in the late glacial was recorded at ca. $16 \mathrm{ka}$, probably as a result of melting glaciers in the uppermost reaches of the lake's main tributary, the Ongin River, and the influx of glacially ground, fine materials. Lake Ulaan had a higher salinity afterward during the Greenland Interstadial 1, and dry climate prevailed in the region. The lake level started to rise and the salinity decreased since ca. $12.3 \mathrm{ka}$, leading to the establishment of freshwater conditions in the early Holocene. Highest inflows and highest productivity in and around the lake, and wettest climate conditions in the region were recorded in the early Holocene. Lake conditions, most favorable for the aquatic fauna, culminated ca. $10 \mathrm{ka}$. Afterward, Lake Ulaan experienced a step-wise lake-level decline and salinity increase at ca. 9.4 and $6.8 \mathrm{ka}$. The further shrinkage of the lake and the approaching Ongin River mouth near the central part of the basin is recorded since ca. $3.2 \mathrm{ka}$.

Keywords: Central Asia, Gobi Desert, late glacial, Holocene, palaeoenvironment, micropalaeontology

\section{INTRODUCTION}

The late glacial and Holocene climate conditions in Central Asia are intensively debated due to the aridity in most parts of the region and the resulting vulnerability of local ecosystems (Chen et al., 2008; Wang et al., 2010). Precipitation arrives in Central Asia with the landward-penetrating East Asian and Indian summer monsoons (EASM and ISM, respectively), and the westerlies. High pressure and dry air predominates over the cooling continental land mass in winter. Future climate change and rapidly increasing population in parts of Central Asia require a good understanding of the potential extent and rapidity or lag times of especially hydrological changes; and periods of rapid warming in the late glacial and Holocene may serve as analogs of future climate change. The 
current understanding of the Holocene climate history in Central Asia is not sufficient, although 101 Holocene climate records were recently analyzed from arid Central Asia (ACA, here defined as Mongolia and Central Asia west of the 110th degree of longitude and north of the Tibetan Plateau and its foreland), from the Tibetan Plateau and from East Asia by Herzschuh et al. (2019). Deficiencies mostly result from the uneven spatial distribution of the available climate records, uncertainties of the established chronologies, and the partly poor sample resolution of records in general or at least for specific periods of the Holocene. The largest gap where climate records were not available in the study by Herzschuh et al. (2019) or those of earlier assessments by Chen et al. (2008) and Wang et al. (2010) remains in the central, southern and eastern parts of Mongolia, covering a distance of ca. $1500 \mathrm{~km}$ from west to east and of ca. $700 \mathrm{~km}$ from north to south. Holocene sediments from the lakes Ulaan, Bayan Tohomin Nuur (BTN), Tatsain Tsagaan Nuur (also written Taatsiin Tsagaan Nuur or Taatsin Tsagaan Nuur; TTN), Orog Nuur (ON) and Uigi Nuur within this region were investigated in studies by Lee et al. (2011, 2013), Wang et al. (2011), Felauer et al. (2012) and Yu et al. (2017, 2019), but chronologies of these lake records are partly very poorly constrained (BTN and ON), or analyses remained cursory so far (TTN), did not include the early Holocene (Uigi Nuur) or focussed on the assessment of different dating techniques and the provenance of accumulated deposits and weathering conditions rather than the climate history (Lake Ulaan; Figure 1). To improve this situation, we investigated the calcareous fossils and additional proxies from the relatively well-dated ULB core from Lake Ulaan in southern Mongolia studied by Lee et al. $(2011,2013)$. Our aim is the reconstruction of climate conditions in the catchment of the lake in the late glacial and Holocene. In addition, we aim to reconstruct the lake ecosystem with a focus on its palaeo-salinity, and to compare the results to the remotesensing-based inference of a large freshwater lake with a surface area of up to $19,000 \mathrm{~km}^{2}$ and an estimated volume of $3150 \mathrm{~km}^{3}$ that possibly existed in the basin in the past and that led to the assumption of a large freshwater aquifer in the region (Sternberg and Paillou, 2015). Sternberg and Paillou (2015, p. 26) concluded "Thus a fossil groundwater resource of unknown quality may still be present in the Ulaan Nuur depression and accessible using current drilling techniques."

Climate in the region of Lake Ulaan is arid with $127 \mathrm{~mm}$ mean annual precipitation (observation period 1982-2012) at the station Dalanzadgad $120 \mathrm{~km}$ to the southeast (Climate-Data.org; Figure 1). More than half of the precipitation falls during the summer months from June to August. However, precipitation is significantly higher in the upper catchment of the Khangai Mountains with ca. 300-400 mm per year, also mostly falling during summer. Mean January, July and annual temperatures in Dalanzadgad are $-14.4,21.2$, and $4.6^{\circ} \mathrm{C}$ (Climate-Data.org).

Lake Ulaan is the easternmost of the Valley of the Gobi Lakes. It has a relatively large catchment area with the $435-\mathrm{km}$ long Ongin River (also Ongi, Ongiin) as its main tributary (Suzuki, 2013; Figure 1). The upper catchment includes the southeastern ranges of the Khangai Mountains as the main source of generated runoff. Exposed bedrock in the southeastern Khangai Mountains mostly represents intensively deformed Devonian sedimentary rocks intruded by late Palaeozoic granitoids (Ganbat and Demberel, 2010). The region around Lake Ulaan is covered by Quaternary unconsolidated alluvial and aeolian sediments.

The lake was a relatively large, endorheic, permanent and generally shallow water body. The surface area of the lake was $65 \mathrm{~km}^{2}$ in the 1960 s or $175 \mathrm{~km}^{2}$ after occasional heavy rains (Tserensodnom, 2000; Lee et al., 2011). Mean and maximum water depths were 0.9 and $1.6 \mathrm{~m}$, respectively, after strong rains (Tserensodnom, 2000). Lake Ulaan was almost completely dry in 1952-1953 (Tserensodnom, 1971). It was a saline lake similar to most of the better known large lakes of the Gobi Valley (Dulma, 1979; Shvartsev et al., 2014; Lehmkuhl et al., 2018).

The lake shrank in the early 1990s when the main inflow of the lake dried as a result of intensely increased placer-gold mining in the middle reaches of Ongin River (Suzuki, 2013). The permanent lake is replaced by a playa since 1995 which is occasionally partly flooded after heavy rains (Beck et al., 2007; Holguín and Sternberg, 2018). Springs are located at the southern margin of the playa and marshy areas support the growth of reed and sedges (Holguín and Sternberg, 2018). Active and partially vegetated dunes are mostly located in the northwest and north of the playa (Lehmkuhl et al., 2018). Their alignment indicates prevailing winds from the northwest. Local vegetation is sparse and dominated by low shrubs and herbaceous plants (Haloxylon, Kalidium, Salsola, Artemisia, Calligonum, Nitraria, Ephedra; Murad, 2011).

\section{MATERIALS AND METHODS}

\section{Summary of Previous Analyses}

The 588-cm long core ULB was obtained from the southern part of Lake Ulaan $\left(44.5139^{\circ} \mathrm{N}, 103.6544^{\circ} \mathrm{E}\right)$ in 2007. The core chronology was established based on optically stimulated luminescence (OSL; 12 samples) and radiocarbon dating (17 samples) by Lee et al. (2011). According to their work, the sediment core represents the lake history of the last $17 \mathrm{ka}$ (Lee et al., 2013). The relatively high mean standard deviation of the twelve OSL-dating ages of $1 \mathrm{ka}$ requires that inferred periods in the discussion below are viewed with caution. However, age data are discussed here with the same precision as was used by Lee et al. $(2011,2013)$ to ensure consistency and to allow useful comparisons. In addition to radiocarbon and OSL age data, grainsize data were presented by Lee et al. (2011). Major element, total organic carbon (TOC), and carbonate concentrations, and $\mathrm{C} / \mathrm{N}$ ratios of sediments of the same core were investigated by Lee et al. (2013).

\section{Measurements of Magnetic Susceptibility}

For measurements of the magnetic susceptibility (MS), sediment cubes of $1 \mathrm{~cm}^{3}$ volume were collected at $1-\mathrm{cm}$ resolution (584 samples) from the core continuously without gaps, and measured using a Bartington MS2 system at the Korea Polar Research Institute. 


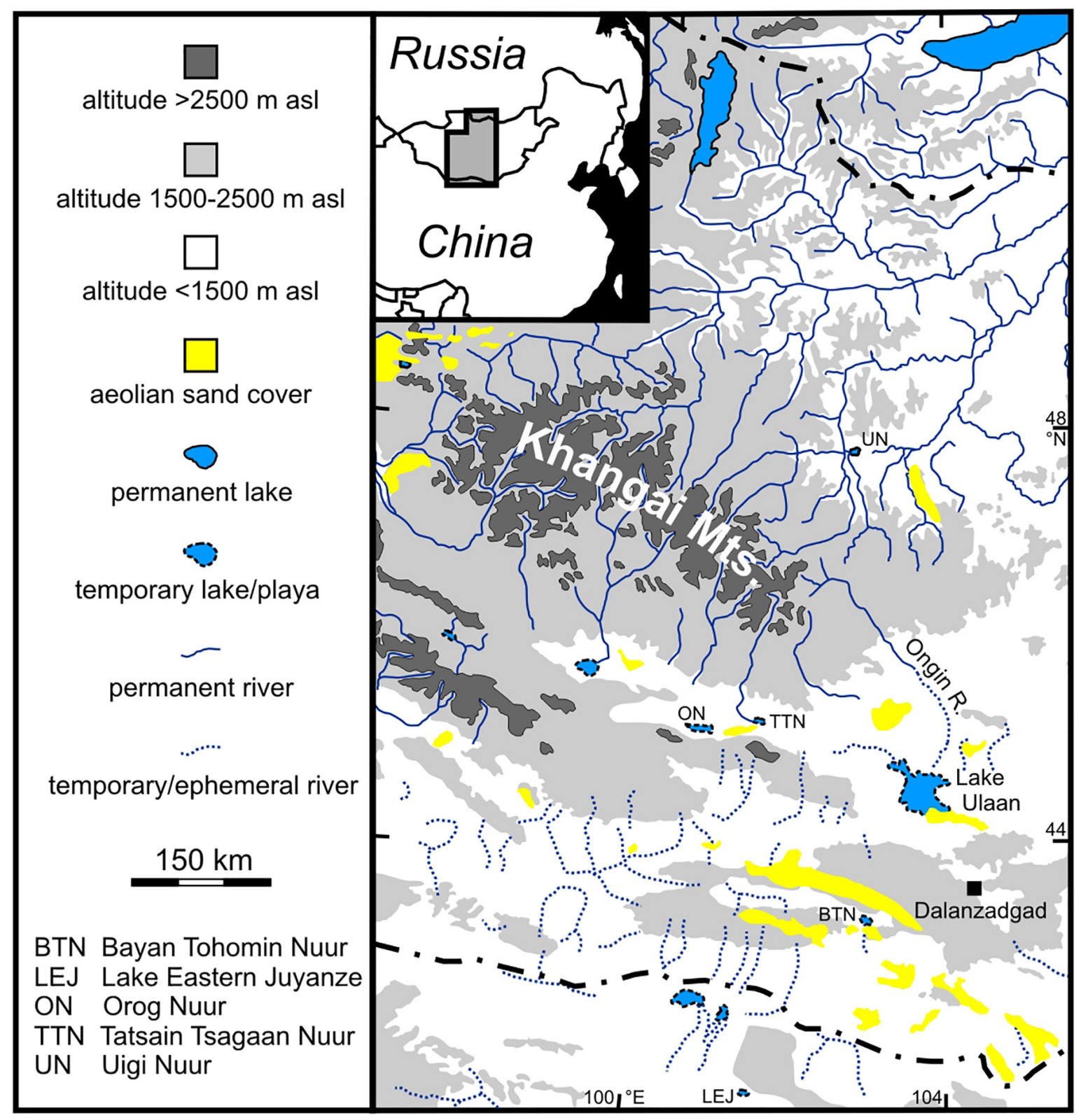

FIGURE 1 | Location of Lake Ulaan and its main tributary, the Ongin River, in Mongolia. Based on Lehmkuhl et al. (2018), modified.

\section{Assessment of Aeolian Sand Contribution}

A rough assessment of the potential contribution of aeolian sand to the sand fraction of the ULB core was conducted by the separation of the 180-250 $\mu \mathrm{m}$ fraction through wet sieving of ten selected samples with known high sand contents based on the initial grain-size analysis of Lee et al. (2011). The 180$250 \mu \mathrm{m}$ fraction was selected as proxy for the aeolian sand contribution because mean grain sizes of aeolian sands of a dune field near ON (Nugin Els dune field) and in the Badain Jaran Desert in the southeast of Lake Eastern Juyanze (LEJ) are ca. $200 \mu \mathrm{m}$ (Hempelmann, 2011; Dong et al., 2013). In addition, the aeolian end member of lake-surface sediments of five lakes in the southeastern part of the Badain Jaran Desert has grain-size frequency distribution curves with modes at a grain size of ca. $200 \mu \mathrm{m}$ (Li et al., 2018).

\section{Analyses of Fossils and Inference of Specific Conductivity}

In total, 48 samples from core ULB were used for palaeontological analysis. On average, $15 \mathrm{~g}$ (8-32 g) of dry sediment was treated with a $3 \%$ solution of $\mathrm{H}_{2} \mathrm{O}_{2}$ for 48 hours. Afterward, sediment was washed through a set of sieves with 90, 250, and $1000 \mu \mathrm{m}$ pore sizes, respectively. 
Ostracod valves were picked from the sieve residues under an Olympus SZ 60 low-power binocular microscope. All valves were picked. Adult and juvenile valves were distinguished separately and identified according to Meisch (2000) and Fuhrmann (2012). A few well-preserved, left valves of adult Ilyocypris specimens were examined with a Zeiss Supra $40 \mathrm{VP}$ Scanning Electron Microscope (SEM) at Freie Universität Berlin and identified as valves of Ilyocypris cf. inermis Kaufmann, 1900 and Ilyocypris cf. bradyi Sars, 1890 based on the marginal ripplets on the inner lamella (van Harten, 1979; Janz, 1994). Valves of Ilyocypris examined under the Olympus SZ 60 microscope were pooled in I. gr. inermis, probably representing the two identified taxa $I$. cf. inermis and $I$. cf. bradyi.

Shells of two gastropod taxa were recorded in the sediments of the core ULB. Shells of Gyraulus, probably belonging to Gyraulus chinensis (Dunker, 1848) or Gyraulus terekholicus (Prozorova et Starobogatov, 1997), were pooled in the group G. gr. chinensis. Shells of Radix are partly damaged, and exclusively represent juvenile specimens. Thus, they were assigned as Radix sp. In addition to ostracod valves and gastropod shells, charophyte remains were recorded.

Major changes in the distribution and abundance of fossils of the Ulaan-Nuur record were used to define six different zones of the core. Other proxies were considered in addition at zone boundaries with low temporal resolution of samples analyzed for fossils.

Past levels of specific conductivity (SC) were estimated as the mutual SC tolerance range for all taxa recorded in a specific sample. Published SC tolerance ranges of the ostracod taxa recorded at Lake Ulaan are based on calibration data sets of transfer functions of Van der Meeren et al. (2012) and Mischke et al. (2007, 2014; Table 1). Gyraulus and Radix are both regarded as freshwater gastropods. G. chinensis is the commonest species in Mongolia and it was recorded in Lake Airag which has a SC of $5.3 \mathrm{mS} \mathrm{cm}^{-1}$ regarded as upper SC tolerance limit here (Van der Meeren et al., 2012; Vinarski et al., 2017; Table 1). Members of the genus Radix such as $R$. balthica with wide distribution in Mongolia, can tolerate relatively brackish conditions with a maximum salinity of $14 \%$ (Jaeckel, 1962). The charophyte Chara vulgaris L. occurs in lakes and rivers in Mongolia, and cultivation experiments suggest an upper salinity limit of ca. 10\% (Winter and Kirst, 1990; Romanov et al., 2014; Table 1). Reported salinity values were converted to SC using the conversion factor of 1.5 recommended by Hem (1982).

\section{Assessment of Holocene Moisture Availability at Other, Previously Studied Locations}

Available moisture during the Holocene was assessed for 89 pollen records from Central and East Asia based on quantitative precipitation reconstructions of Herzschuh et al. (2019). Reconstructed precipitation for the early, middle and late Holocene of each studied location was assigned to three categories: (1) dry, (2) moderate, and (3) wet. In addition to these 89 records, twelve relevant Holocene lake-sediment and speleothem records from northwestern China and Mongolia not included in the study of Herzschuh et al. (2019) were assessed using the same three categories.

\section{RESULTS}

The recorded MS values in the core ULB range from 4.8$36.1 \times 10^{-5}$ SI with an average of $15.6 \times 10^{-5}$ SI (Figure 2). The MS increases from the base to ca. $411 \mathrm{~cm}$ core depth (ca. $11.7 \mathrm{ka})$, decreases from 411 to ca. $355 \mathrm{~cm}(11.7-10.1 \mathrm{ka})$, remains close or slightly beneath average between 355 and $114 \mathrm{~cm}(10.1-3.2 \mathrm{ka})$ and is higher than average above $114 \mathrm{~cm}$ ( $<3.2 \mathrm{ka}$; Figure 2).

In total, 1559 ostracod valves were recorded in 40 samples from the core ULB (Figure 3). Eight samples did not contain ostracod valves. Most valves (1425) represent the species Limnocythere inopinata (Baird, 1843; Figures 3, 4). I. gr. inermis was recorded with 97 valves, Cypridopsis vidua (Müller, 1776) with 22 valves, Heterocypris salina with nine valves and both, Pseudocandona sp. and Sarscypridopsis aculeata (Costa, 1847) with three valves, respectively. The majority of valves (ca. 85\%) are those of juvenile specimens.

Gastropod shells of two different taxa were recovered from the sixth part of the samples: 42 shells of $G$. gr. chinensis were recorded in a total of seven samples, and twelve shells of Radix sp. were found in four samples.

In addition, 65 gyrogonites and four oospores of the charophyte C. vulgaris were recorded in a total of 19 sediment samples (Figures 3, 4).

\section{DISCUSSION}

\section{The MS Data and Their Relation to Grain Size and Other Proxies}

The MS of lacustrine sediments is a proxy for the concentration of ferromagnetic iron oxides such as (titano)magnetite and maghemite and potentially for iron sulfides such as greigite (Hatfield et al., 2020). The MS data of the ULB core show relatively systematic trends within four core sections which are separated by rapid changes at $11.7 \mathrm{ka}(411 \mathrm{~cm}), 10.1 \mathrm{ka}(355 \mathrm{~cm})$, and $3.2 \mathrm{ka}(114 \mathrm{~cm}$; Figure 2$)$. The rapid changes and trends such as the continuous decrease from high values at $11.7 \mathrm{ka}$ to the minimum at $10.1 \mathrm{ka}$ are apparently not controlled by grainsize variations in the sediment core which change most rapidly at $15.2 \mathrm{ka}(534 \mathrm{~cm})$ and $11.1 \mathrm{ka}(390 \mathrm{~cm})$. In contrast, MS variations are apparently at least partly controlled by concentrations of $\mathrm{CaCO}_{3}$ and TOC. The continuous MS decrease between 11.7 and $10.1 \mathrm{ka}$ is accompanied by the strongest increase of the $\mathrm{CaCO}_{3}$ and TOC concentrations showing that dilution effects due to the contribution of carbonate and organic matter (OM) are significant. Pearson correlation coefficients for MS and $\mathrm{CaCO}_{3}$ or MS and TOC in this section of the core are -0.9 and -0.8 , respectively. However, there is no correlation between these parameters or MS and mean grain size if the complete data set is considered (Pearson's $r$ is $0.1,0.3$, and -0.3 , respectively). Lee et al. (2013) demonstrated in their study of the provenance of the detrital sediments of the ULB core that their origin changed over 
TABLE 1 | Published specific conductivity (SC) tolerance ranges (minima and maxima) for taxa recorded in the sediments of Lake Ulaan.

\begin{tabular}{|c|c|c|c|c|}
\hline Taxon & SC min. & SC max. & $n$ & References \\
\hline Limnocythere inopinata & 1.1 & 6.6 & 46 & Van der Meeren et al., 2012 \\
\hline Ilyocypris cf. bradyi* & 0.4 & 0.9 & 13 & Van der Meeren et al., 2012 \\
\hline Ilyocypris cf. inermis\# & 0.7 & 3.0 & 11 & Van der Meeren et al., 2012 \\
\hline Heterocypris salina & 0.7 & 6.3 & 85 & Mischke et al., 2014 \\
\hline Pseudocandona & 0.3 & 1.3 & 11 & Van der Meeren et al., 2012 \\
\hline Sarscypridopsis aculeata & 2.6 & 17.0 & 8 & Mischke et al., 2007 \\
\hline Cypridopsis vidua & 0.3 & 0.8 & 9 & Van der Meeren et al., 2012 \\
\hline Gyraulus chinensis & 0.0 & 5.3 & & Van der Meeren et al., 2012; Vinarski et al., 2017 \\
\hline Radix balthica & 0.0 & 21.5 & & Jaeckel, 1962 \\
\hline Chara vulgaris & 0.0 & 16.0 & & Winter and Kirst, 1990 \\
\hline
\end{tabular}

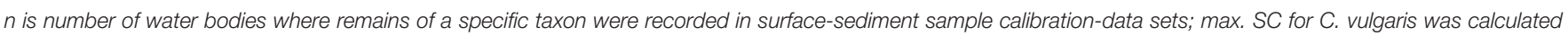

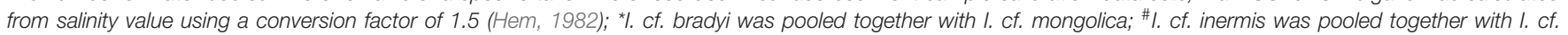
decipiens.

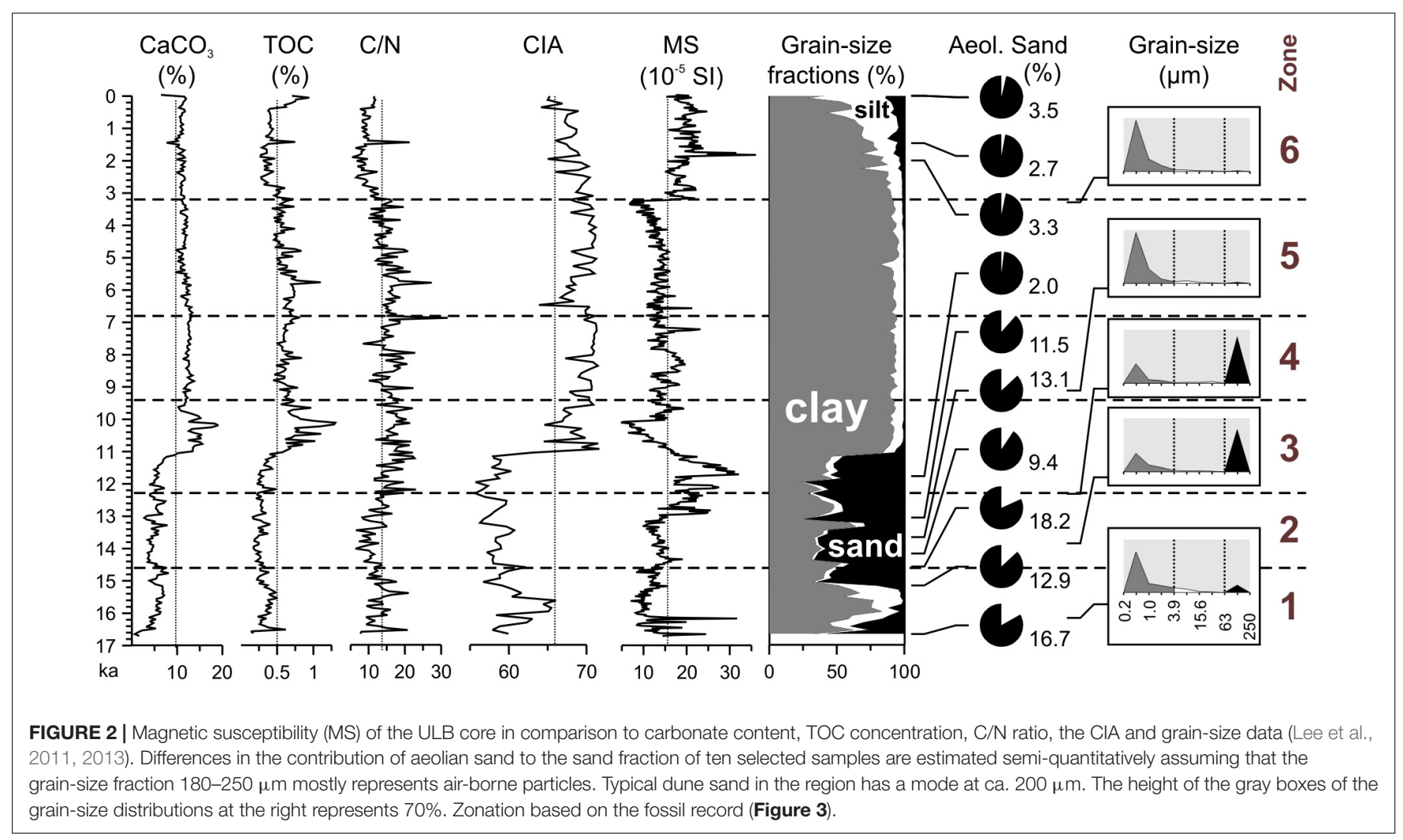

time. Thus, the MS data are not easily interpreted as a proxy of a single controlling factor.

In comparison to other late glacial and Holocene lake sediments from the Valley of the Gobi Lakes or further south, the sediments from Lake Ulaan have significantly higher clay $(73 \%$ on average for the entire core) and lower silt (11\%) contents (Figure 2). For example, sediments from BTN ca. $110 \mathrm{~km}$ to the south-southwest, TTN ca. $190 \mathrm{~km}$ to the west-northwest, or ON ca. $240 \mathrm{~km}$ to the west-northwest, have significantly higher silt contents of ca. 65, 85, or 60\%, respectively (Felauer et al., 2012; Yu et al., 2017; Lehmkuhl et al., 2018; Figure 1). However, the silty lake deposits from BTN have the main grain size mode at ca. $5 \mu \mathrm{m}$ (i.e., very fine silt), close to the grain-size classification boundary between silt and clay at $3.9 \mu \mathrm{m}$ (Felauer et al., 2012). Grainsize analysis was conducted at Lake Ulaan by wet sieving of the fraction coarser than $63 \mu \mathrm{m}$ and using a Micromeritics Sedigraph 5100 device for the finer fraction. In contrast, a laser diffraction particle size analyzer was used for analyses of sediments from $\mathrm{ON}$ and BTN (Felauer et al., 2012; Yu et al., 2017). Wet sieving of the fraction $>63 \mu \mathrm{m}$ and the pipette method for the finer fraction were applied to sediments from TTN (Lehmkuhl et al., 2018). Comparative analyses of sediments for the application of the Sedigraph and the laser diffraction particle size analyzer revealed typically a ca. $20 \%$ higher clay content of sediments analyzed 


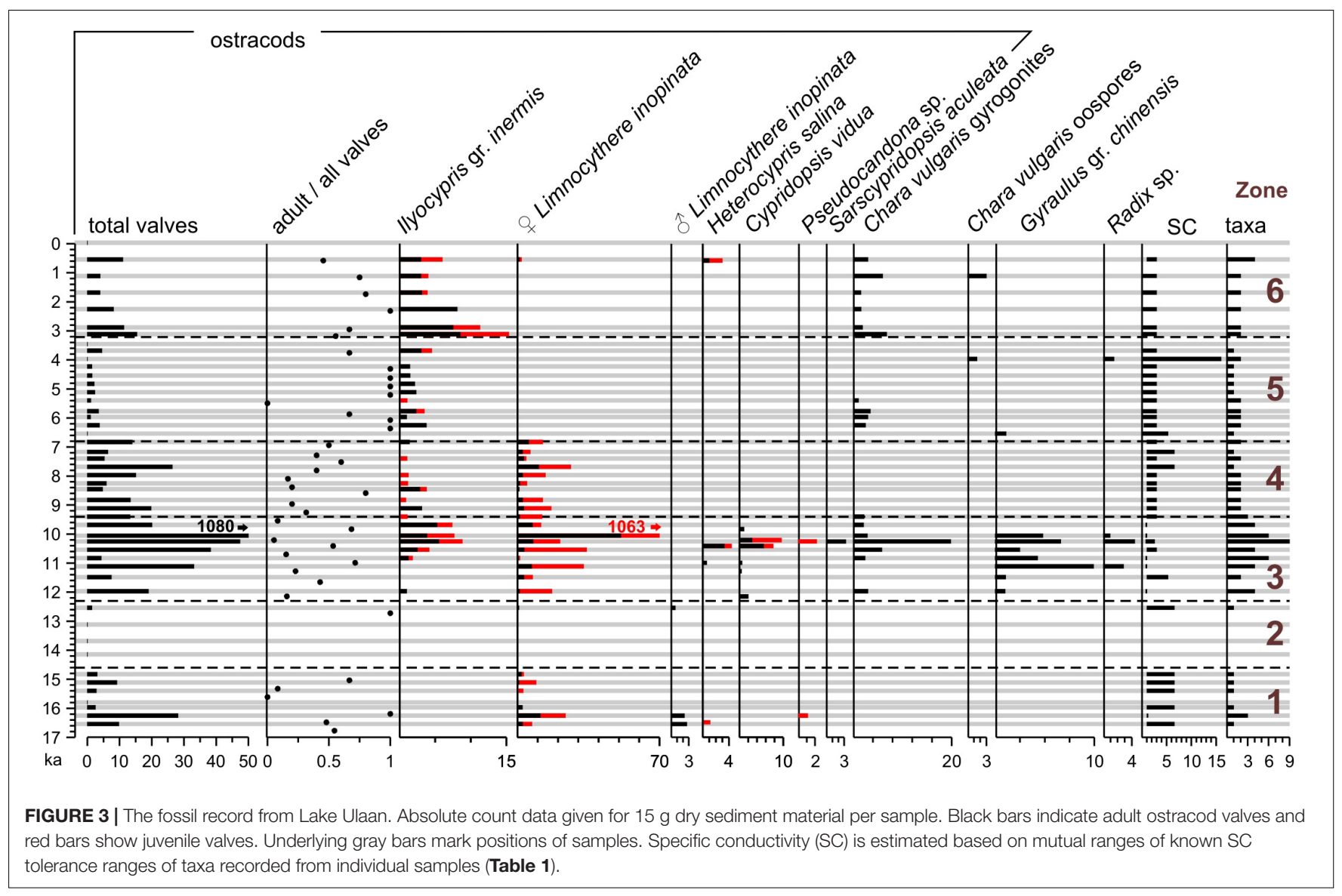

using a Sedigraph device at the expense of the silt fraction (Magno et al., 2017). Also the Sedigraph approach typically resulted in higher contents of fine materials in comparison to the pipette approach (Buchan et al., 1993; Müller et al., 2009). However, it remains unclear whether the high clay and low silt contents in the sediments of the ULB core in comparison to nearby Gobi-Desert lakes reflect methodological differences in grain-size analysis of generally very clay or very fine-silt-rich sediments, or possibly different particle-transport controls and different depositional settings.

\section{The Ostracod Assemblage and Other Fossils From Lake Ulaan}

Observed changes in the abundance of fossil remains in the ULB core were used to differentiate six distinct periods in the history of Lake Ulaan since $17 \mathrm{ka}$ (Figure 3). The ostracod assemblage from Lake Ulaan is largely dominated by the species L. inopinata. The species was recorded as the most widely distributed ostracod taxon in modern lakes in western and central Mongolia where it was present in 46 of the investigated 56 lakes (Van der Meeren et al., 2012). A similar dominance of the species in late glacial and Holocene sediments was also observed at other Gobi-Desert lakes such as ON and Eastern Juyanze (ca. $330 \mathrm{~km}$ in the south-southwest; Mischke et al., 2002; Yu et al., 2019; Figure 1). In contrast, and unexpected considering its wide distribution and wide ecological tolerances, the species is completely absent from the fragmentary late glacial and Holocene ostracod record of BTN (Meisch, 2000; Felauer et al., 2012).

Valves of $I$. cf. inermis and I. cf. bradyi were recorded in the sediments of Lake Ulaan and also in the late Pleistocene deposits of ON (Yu et al., 2019). In addition, those of the probably more freshwater-restricted I. cf. bradyi were also found in the Holocene deposits of ON, of BTN and of LEJ (Mischke et al., 2002; Felauer et al., 2012). The species C. vidua and H. salina were both recorded in Lake Ulaan, the BTN and in LEJ. Valves of Pseudocandona sp. were recovered (partly as $P$. cf. compressa or $P$. compressa) from all four lakes including also ON. A few valves of S. aculeata were not only recorded in the sediments from Lake Ulaan but also in those of ON and LEJ.

In addition to ostracods, the gastropods G. gr. chinensis and Radix sp., and charophyte oospores and gyrogonites were recorded in Lake Ulaan. Shells of Gyraulus and Radix, and charophyte oospores were also reported from LEJ whilst similar remains were not recorded in the sediments of $\mathrm{ON}$. A few gastropod shells and shell fragments were separated from the sediments of BTN but were not identified (unpublished data $S$. Mischke).

In contrast to the ostracod records from the other three Gobi-Desert lakes, valves of Candona, Neglecandona, and Fabaeformiscandona, and of the species Darwinula stevensoni 


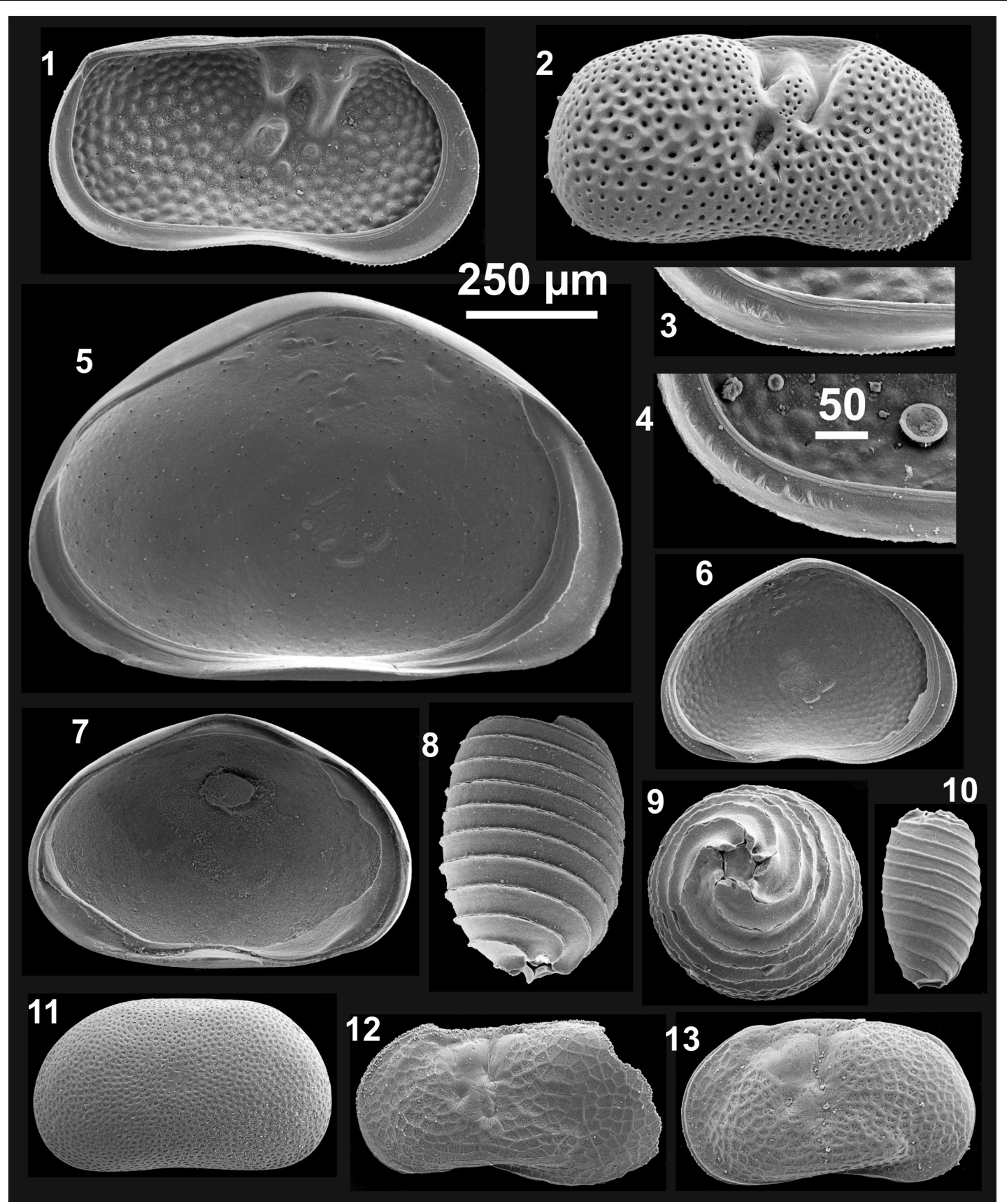

FIGURE 4 | Recorded fossils from Lake Ulaan. 1 llyocypris cf. inermis left valve (LV) internal view (iv); 2 I. gr. inermis right valve (RV) external view (ev); 3 I. cf. inermis, marginal ripplets on posteroventral part of inner lamella; 4 Ilyocypris cf. bradyi, marginal ripplets on posteroventral part of inner lamella; 5 Heterocypris salina LV iv; 6 Sarscypridopsis aculeata LV iv; 7 Cypridopsis vidua LV iv; 8-10 Chara vulgaris, 8 gyrogonite lateral view, 9 gyrogonite basal view, 10 oospore lateral view; 11 Pseudocandona sp. (juvenile) LV ev; 12, 13 Limnocythere inopinata, $12 \mathrm{o}^{\mathrm{L}} \mathrm{LV}$ ev, 13 q LV ev. Scale bar is $250 \mu \mathrm{m}$ apart for 3 and 4 . Specimens housed at Institute of Geological Sciences of the Free University of Berlin (Germany).

were not recovered from the ULB core, possibly suggesting that Lake Ulaan was a permanent and relatively brackish lake which was not supporting taxa with freshwater to slightly brackish-water preferences. Among these taxa, only D. stevensoni reached high abundances in the Holocene sediments of one of the other three records - that from Eastern Juyanze.
Van der Meeren et al. (2012) reported a maximum SC tolerance of ca. $0.6 \mathrm{mS} \mathrm{cm}^{-1}$ for D. stevensoni in Mongolia based on six water bodies where the species was recorded. Thus, the absence of valves of $D$. stevensoni from the sediments of the Lake-Ulaan record possibly implies that the water was never as fresh as $0.6 \mathrm{mS} \mathrm{cm}^{-1}$ during the late glacial and Holocene. However, the 
species was observed to tolerate significantly higher salinities in other regions (Meisch, 2000).

The predominance of valves of $L$. inopinata ( $91 \%$ of all valves) in sediments of Lake Ulaan is comparable to almost monospecific assemblages of 16 lakes among 440 investigated modern lakes of the Tibetan Plateau and in Xinjiang, Inner Mongolia, Heilongjiang (all China) and Mongolia where the relative abundance of the species' valves in surface-sediment samples was exceeding 90\% (Mischke et al., 2007; and additional unpublished data S. Mischke). Altitude, SC, concentration of dissolved oxygen and other key parameters of these 16 lakes cover large gradients whilst all 16 lakes have shallow water depths ranging from $0.08-2.10 \mathrm{~m}$ and high sodium-ion and low calcium-ion concentrations (42-99\% and $0-27 \%$ of the cations, respectively) in common (unpublished data S. Mischke). Thus, the ostracod assemblage from Lake Ulaan implies that the lake was probably mostly shallow and waters were likely dominated by sodium due to evaporative concentration and removal of calcium by carbonate precipitation in a terminal lake. The inference of Holocene lake levels 44, 124, and $259 \mathrm{~m}$ above the present dry basin surface based on remote-sensing data of structures interpreted as palaeo-shorelines is not supported by the ostracod record from Lake Ulaan (Sternberg and Paillou, 2015). In contrast, lake levels of 2-3 $\mathrm{m}$ above the dry basin floor described by Lehmkuhl et al. (2018) for the most recent highstand until the 1960s are consistent with the predominance of L. inopinata and the mono-specific or almost mono-specific occurrence of the species' in very shallow modern lakes in Central Asia.

\section{Late Glacial and Holocene History of Lake Ulaan \\ Zone 1: 17-14.6 ka (588-512 cm)}

Apart from one sample, sediments of Zone 1 contain only ostracod valves of $L$. inopinata. Valves represent both juvenile and adult specimens, indicating that they probably not experienced post-mortem transport and re-deposition (Figure 3). Valves of $H$. salina and Pseudocandona sp. were recorded in one sample, with the former suggesting shallow, fluctuating, possibly temporary and slightly brackish conditions (Meisch, 2000). The low species diversity and dominance of L. inopinata suggests that Lake Ulaan was a very shallow lake with sodium-dominated water. Low TOC concentrations and $\mathrm{C} / \mathrm{N}$ ratios of ca. 13 in Zone 1 indicate that bioproductivity in the lake was low and that OM mostly derived from lake productivity and not from terrestrial vegetation. The detrital sediment fraction shows a bimodal grain-size frequency distribution with similarly large clay and sand fractions near the base and top of Zone 1 (Lee et al., 2013; Figure 2). The clay fraction increases in the middle of the zone similar to the silt fraction, and both decrease in the upper part at the expense of the sand fraction. Ca. $17 \%$ of the sand fraction of a sample from the lower part of the zone is in the size range from 180 to $250 \mu \mathrm{m}$ which encompasses the particle-size distribution mode of typical dune sand in the region, suggesting that a significant fraction of the sand was not transported to Lake Ulaan by the Ongin River but by wind (Hempelmann, 2011; Dong et al., 2013; Li et al., 2018). Lee et al. (2011) already argued that the accumulation of detrital sediments in Lake Ulaan was dominated by aeolian processes with the fine fraction representing locally derived dust and the coarse fraction representing aeolian sands. The fine fraction of Zone 1 was geochemically traced to originate from the Gobi Altai terrane by Lee et al. (2013). The increase of the clay but also of the silt fraction in the middle of the zone requires a different explanation. The parallel increase of clay and silt contents at ca. $16 \mathrm{ka}$ can be possibly explained by two different processes: (1) the decrease of storm frequencies and wind strength, leading to a lower influx of aeolian sand in Lake Ulaan, or (2) a higher contribution of suspended sediments of runoff entering Lake Ulaan. The latter could have resulted from increased runoff in general, or from a higher suspension load of the Ongin River, possibly caused by a higher meltwater contribution to the drainage of the catchment. The last major late glacial glacier advances in the Khangai Mountains were dated to ca. $18-17$ or $17-16 \mathrm{ka}$, and melting of glaciers and the release of glacially ground materials (i.e., rock flour, glacial milk) and subsequent transport and deposition in Lake Ulaan possibly caused the increase of the clay and silt fraction ca. $16 \mathrm{ka}$ (Rother et al., 2014; Pötsch et al., 2015). Alternatively, fluvial sediment accumulation and lake-level changes or re-locations of the Ongin River delta in Lake Ulaan cannot explain the detrital sediment-accumulation change from the base to the middle of Zone 1, because an increasing lake level (or larger distance to the delta and shores) would result in a decreased accumulation of fluvial grains in comparison to air-borne particles at the core site. In contrast, a falling lake level (or closer delta position or distance to the shores) should lead to a decrease of the clay fraction and increase of fluvially transported silt and sand grains, accompanied by a higher influx of aeolian sands. Thus, accumulation of aeolian sand during storms, clay-sized dust particles following stormy days and during windy days, and suspended particles from the Ongin River better explains the observed grain-size pattern in the middle of Zone 1 .

The weathering proxy CIA increases in the middle of Zone 1, obviously mirroring the significant grain-size changes and not necessarily tracing changes in weathering or climate conditions (Figure 2).

\section{Zone 2: 14.6-12.3 ka (512-430 cm)}

Ostracod valves are almost completely absent in Zone 2 (Figure 3). One sample from Zone 2 contains a few adult valves of $L$. inopinata which are not accompanied by juvenile valves, and it is not possible to rule out that these valves were not reworked from older deposits or transported by currents from other locations in the lake. The almost complete lack of organism remains could have resulted from (1) the desiccation of Lake Ulaan, (2) the establishment of hypoxic conditions, or (3) the increase of the salinity above the tolerance maxima of the lake dwellers. The relatively high clay content and low $\mathrm{C} / \mathrm{N}$ ratios in Zone 2 show that Lake Ulaan was not dry and that fine-grained dust particles were trapped on the lake surface. The sand fraction is ca. $55 \%$ in the zone, and the fraction within the $180-250 \mu \mathrm{m}$ range is relatively high, suggesting that the influx of aeolian sand was significant. The inference of hypoxic conditions and related enhanced OM preservation is not supported by the low 
TOC concentrations in Zone 2. Thus, conditions were apparently too brackish to support a thriving ostracod population in Lake Ulaan. Based on upper tolerance boundaries of $L$. inopinata, $H$. Salina, and Pseudocandona sp., conductivities exceeded probably $7 \mathrm{mS} \mathrm{cm}{ }^{-1}$ (equivalent to a salinity of $4.5 \%$; Hem, 1982; Table 1). Low $\mathrm{CaCO}_{3}$ and TOC concentrations support the inference of more brackish conditions: relatively low inflows resulted in insignificant precipitation of authigenic carbonate from the water column, and relatively high salinity suppressed bioproductivity of the lake. Relatively brackish conditions of the lake may have resulted from arid climate conditions and low inflows and high evaporation due to the first significant late-glacial warming because sediments of Zone 2 accumulated more or less during the period of the Greenland Interstadial 1 (GI-1; 14.7-12.9 ka; Lowe et al., 2008). The lower and upper boundaries of Zone 2 are only poorly constrained due to a poor sample resolution for analysis of fossils and the relatively low sediment-accumulation rate with the two neighboring samples representing ages of 14.8 and $14.1 \mathrm{ka}$ at the lower boundary or ages of 12.5 and $12.0 \mathrm{ka}$ at the upper one, respectively. Low $\mathrm{C} / \mathrm{N}$ ratios indicate that terrestrial vegetation around the lake was sparse, supporting the inference of arid climate conditions. C/N ratios slightly increase from the middle of Zone 2 toward the top. However, increasingly wetter climate toward to the zone's top is not indicated by the generally low CIA. MS values, increasing toward the zone's top, possibly also suggest sparse-vegetation cover and increasing soil erosion. The slight $\mathrm{C} / \mathrm{N}$ ratio increase in the upper half of Zone 2 results probably from the establishment of a reed belt along the lake shore or enlargement of the reed belt rather than increasing density of terrestrial vegetation in the region. Reed was widely distributed in the marshy areas of the lake basin in 2015, and it is the taxon Phragmites australis which is widely distributed in the marshy areas of the Valley of the Gobi Lakes (Gunin et al., 1999; Orkhonselenge et al., 2018). Modern $P$. australis in northeastern China has a mean $\mathrm{C} / \mathrm{N}$ ratio of 18 , similar to $\mathrm{C} / \mathrm{N}$ ratios near the top of Zone2, and typically higher values in southern China (Liu et al., 2015; Jia et al., 2018).

\section{Zone 3: 12.3-9.4 ka (430-331 cm)}

Ostracod valves reach relatively high numbers in Zone 3 , and valves include both juvenile and adult specimens and are dominated by the former, suggesting that they represent autochthonous death assemblages which were not affected by post-mortem transport (Figure 3). The assemblage has a relatively high diversity with up to six species recorded from a single sample. The assemblage is dominated by $L$. inopinata with relative abundances of $75 \%$ on average. Valves of $I$. gr. inermis occur in all samples from the upper half of the zone. Shells of G. gr. chinensis and gyrogonites of C. vulgaris are relatively abundant too. G. chinensis is widely distributed in Mongolia today and common in a wide range of habitats including large mountain lakes, rivers, ponds, and pools (Glöer et al., 2014; Vinarski et al., 2017). It was recorded in fresh to slightly brackish waters in Mongolia (Van der Meeren et al., 2012; Table 1). However, SC estimates based on the mutual tolerance ranges of the taxa recorded in the sediments of Zone 3 suggest that Lake Ulaan was probably mostly a freshwater lake during the formation of Zone 3. The abundant charophyte remains indicate that the lake was relatively shallow and that the delta of the Ongin River was probably relatively distant to the core position, causing sufficient light penetration to the lake floor. According to the OSL-dating based age-depth relationship of Lee et al. (2011), sediment formation during Zone 3 is equivalent to the time of the second half of the Greenland Stadial 1 [GS-1 (Younger Dryas); 12.9-11.7 ka] and most of the early Holocene.

$\mathrm{CaCO}_{3}$ and TOC concentrations remained relatively constant and low during the initial period of Zone 3 (i.e., the second half of GS-1), suggesting that inflows to the lake and productivity in its waters remained low. The CIA increased slightly during this period, starting at lowest values for the entire record. MS values fluctuated and reached a maximum near the end of the GS-1, probably resulting from further enhanced soil erosion. The inference of low inflows to Lake Ulaan and low productivity in the lake, and a decreasing salinity is consistent with colder temperatures and lower evaporation effects as would be expected for the time of the GS-1. The 180-250 $\mu \mathrm{m}$ fraction of sand in a sample from the top of the GS-1 is significantly smaller than the values determined for earlier periods showing that the influx of aeolian sand to Lake Ulaan was significantly reduced.

$\mathrm{CaCO}_{3}$ and $\mathrm{TOC}$ concentrations show a slight increase in the initial period of the early Holocene before they increase more significantly and reach maximum values ca. $10 \mathrm{ka}$ (Figure 2). Increasing runoff entering the lake and higher bioproductivity, probably as a result of warmer temperatures, are inferred. The MS values decrease constantly from the beginning of the Holocene to 10.1 ka probably as a result of decreasing soil erosion. $\mathrm{C} / \mathrm{N}$ ratios of 18 on average, similar to the average ratios for $P$. australis in northeastern China today, suggest that a dense reed belt surrounded Lake Ulaan (Liu et al., 2015). Shells of Radix sp. first occurred during the early Holocene. The $\mathrm{CaCO}_{3}$ and TOC maxima, the corresponding MS minimum and the highest diversity of fossil remains at ca. $10 \mathrm{ka}$ probably represent the wettest and warmest conditions in the early Holocene in southern Mongolia. The TOC and $\mathrm{CaCO}_{3}$ concentrations, the $\mathrm{C} / \mathrm{N}$ ratios and ostracod valve abundances decrease abruptly after $10 \mathrm{ka}$, suggesting a return to less favorable conditions. Lee et al. (2011) explained the lowest difference between radiocarbon- and regressed OSLdating results at $350 \mathrm{~cm}$ (ca. $10 \mathrm{ka}$ ) in the ULB core as result of the lowest influence of old reworked carbon and based their inference of most humid conditions on this observation. Thus, different lines of evidence (the fossil assemblage, the $\mathrm{CaCO}_{3}$ and TOC maxima, the age difference between radiocarbon- and OSL-age data) suggest that wettest conditions occurred at Lake Ulaan ca. $10 \mathrm{ka}$.

The abrupt sedimentary change from bimodal clay- and sandrich sediments to clayey sediments at ca. $11 \mathrm{ka}$ is accompanied by a similarly abrupt change of the CIA, apparently reflecting grainsize changes rather than rapidly changing weathering conditions. In addition, it is accompanied by the occurrence of high numbers of G. gr. chinensis shells and the first occurrence of Radix 
sp. in the record, but not by rapid changes of other proxies. Thus, a threshold mechanism apparently decreased the influx of sand-sized particles in Lake Ulaan, possibly related to habitat conditions for the gastropod fauna. We may speculate that the increasing lake size, possibly in conjunction with the enlargement of the reed belt upwind of the core location and in the delta region, largely reduced the accumulation of fluvial and aeolian sand at ca. $11 \mathrm{ka}$. Reed provides an important micro-habitat for gastropods, and the maximum in G. gr. chinensis shells at ca. $11 \mathrm{ka}$ possibly reflects a significant increase in the spatial distribution and density of emergent vegetation in Lake Ulaan (Glöer and Pešić, 2007).

\section{Zone 4: 9.4-6.8 ka (331-238 cm)}

The lower number of ostracod valves and the reduced species diversity of only two taxa suggest that habitat conditions became less favorable during the formation of sediments of Zone 4 . Charophyte remains are almost absent and gastropod shells were not recorded (Figure 3). Lower $\mathrm{CaCO}_{3}$ and TOC concentrations point to reduced inflows and lower bioproductivity, and increased salinities in Lake Ulaan in the last third of the early and first half of the middle Holocene (Figure 2). Larger fluctuations of $\mathrm{C} / \mathrm{N}$ ratios and generally higher MS values probably suggest sporadic influxes of terrestrial $\mathrm{OM}$ and increased soil erosion. The detrital particles remain dominated by the clay fraction. The CIA is high apart from three short-lived minima at ca. 9.2, 8.7, and $8.1 \mathrm{ka}$, indicating efficient weathering conditions. However, generally drier climate conditions and an increased salinity of Lake Ulaan in comparison to conditions during the previous zone are inferred for the period of Zone 4 based on the other proxies.

\section{Zone 5: 6.8-3.2 ka (238-114 cm)}

Very low ostracod-valve numbers and the predominance of valves of adult Ilyocypris specimens suggest that the ostracod assemblage of Zone 5 mostly or exclusively represents allochthonous specimens (Figure 3). I. bradyi commonly inhabits slowly flowing waters, and it is likely the case that the recorded valves of Zone 5 were transported to the core site by wave-driven currents (Meisch, 2000). The inferred absence of autochthonous ostracod valves in Zone 5 probably results from relatively brackish conditions in the lake with a salinity that exceeded the upper tolerance limits of commonly recorded taxa. The slightly decreasing $\mathrm{C} / \mathrm{N}$ ratios probably suggest that OM from Phragmites or terrestrial vegetation contributed less to the OM accumulation at the core location. The CIA and MS values are more or less comparable to those of the previous zone (Figure 2).

Lehmkuhl et al. (2018) described a "smoothened beach ridge" at the position of their investigated UN1 section ca. $10 \mathrm{~km}$ northeast of the core location and ca. $13 \mathrm{~m}$ above the dry lake floor. They reported two middle Holocene radiocarbon and OSL ages for a humic silt and fine sand layer at $100 \mathrm{~cm}$ depth (4.4 ka) and fluvial sand at $160 \mathrm{~cm}(7.8 \mathrm{ka})$, respectively. They used the 1040-m altitude contour to estimate a middle Holocene lake extent of ca. $500 \mathrm{~km}^{2}$ due to "missing well expressed shore lines" (Lehmkuhl et al., 2018). However, it is questionable that the beach-bar remnants were formed contemporaneously with the humic layer regarded as lacustrine sediment due to the layer's position $100 \mathrm{~cm}$ beneath the shoreline deposits. Instead, the 4.4-ka age of the humic layer represents the time when aquatic conditions, lacustrine or possibly spatially more restricted wetland conditions, existed at their section location. The 4.4-ka age should be further regarded as maximum age for the formation of the shoreline deposit on the surface of the UN1 section. However, the ULB-core record does not provide supporting evidence for a 13-m high lake level and generally wet conditions at $4.4 \mathrm{ka}$ or afterward (see below).

\section{Zone 6: 3.2 ka to Present $(114-0 \mathrm{~cm})$}

Ostracod-valve numbers are higher in Zone 6 again, and they represent both juvenile and adult valves (Figure 3). However, they almost exclusively originate from $I$. gr. inermis including valves of $I$. cf. bradyi which is regarded as a river- and streamdwelling species. Apart from one sample including a few valves of $H$. salina, valves of other ostracod species were not recorded in Zone 6. Gastropod shells are also lacking, pointing to a relatively high salinity of Lake Ulaan. Gyrogonites of C. vulgaris were consistently recorded in the sediments of Zone 6, indicating that Lake Ulaan was relatively shallow and that the transparency of water was sufficient for macro-algae growth. C. vulgaris has an upper SC tolerance of $16 \mathrm{mS} \mathrm{cm}^{-1}$ (salinity of ca. 10.4\% ; Hem, 1982; Table 1). The salinity of Lake Ulaan was probably close to the upper tolerance limit of C. vulgaris and we assume that the $I$. cf. inermis valves originate from the approaching Ongin River mouth. This scenario is supported by sedimentological evidence. The silt and sand fractions increase continuously at the expense of clay-sized particles from the lower zone boundary at $3.2 \mathrm{ka}$ toward the top (Figure 2). The $180-250 \mu \mathrm{m}$ fraction of the sand is constantly low, suggesting that the influx of aeolian sand was insignificant. Thus, the continuously increasing silt and sand proportions indicate a gradual decrease of the lake level, and the Ongin River mouth approaching the core position. The CIA decreases in Zone 6, probably reflecting the gradual grain-size increase rather than changing weathering conditions.

The initial decrease of the $\mathrm{C} / \mathrm{N}$ ratios at the base of Zone 6 and mostly low ratios afterward suggest that OM production resulted mostly from phytoplankton growth. In contrast, Phragmites or terrestrial catchment vegetation did not contribute significantly to the OM accumulation in Lake Ulaan in the late Holocene. The MS values show an abrupt rise at $3.2 \mathrm{ka}$ and increase slightly afterward, probably as a result of lower $\mathrm{CaCO}_{3}$ and TOC concentrations at the zone base and increased soil erosion in the catchment of the lake. The inferred lake-level decrease since 3.2 and related lowering of the base level probably resulted in down-cutting of tributaries and soil erosion in the vicinity of Lake Ulaan.

The TOC concentrations are mostly low in the late Holocene due to low productivity in relatively saline lake waters and the poor preservation of $\mathrm{OM}$ in a shallow lake. The TOC concentrations increase significantly near the core top, starting ca. 350 years ago. The strong TOC concentration increase possibly reflects the onset of significant human impact due to 
increasing livestock numbers in the lake's catchment and the related higher influx of nutrients in the lake. Human impacts on environments in Mongolia beyond the most recent decades were rarely addressed so far but charcoal records from western Mongolia were assessed and used to relate declining charcoal concentrations in lake sediments to increasing livestock numbers following the establishment of the Manchu rule in the late seventeenth century (Umbanhowar et al., 2009). Miehe et al. (2007) interpreted pollen data from the southern Gobi Altai (ca. $50 \mathrm{~km}$ southwest of Dalanzadgad; Figure 1) as proxy of drier climate conditions since ca. $1600 \mathrm{CE}$ but they also speculated that the observed increase of Artemisia, Potentilla-type and Brassicaceae pollen resulted from increased animal husbandry.

\section{Comparison With Regional Climate Records}

Significantly less brackish conditions in Lake Ulaan, causing more or less freshwater conditions in the early Holocene, were first established at ca. $12.3 \mathrm{ka}$ in the middle of GS-1. Wetter conditions during the GS-1 are typically not inferred from other climate records from Central Asia due to the assumption of generally cold and dry conditions in the region ( $\mathrm{Li}$ et al., 2011; Goldsmith et al., 2017; Yu et al., 2019). Considering the assumed constant sediment accumulation rate (SAR) for the ULB core which is implied by the simple linear regression of the OSL age data used for the establishment of the age-depth relationship by Lee et al. (2011), the timing of the initiation of less brackish conditions in Lake Ulaan is possibly not well constrained. Assuming that the SAR changed over time and using linear interpolation between the two OSL ages below and above the boundary between Zones 2 and 3 results in a slightly earlier inferred establishment of less brackish conditions in Lake Ulaan at ca. $12.7 \mathrm{ka}$, almost contemporaneous with the beginning of the GS-1. Thus, different ways of age-data assessments support the inference that wetter conditions were established in Lake Ulaan's catchment sometime during the GS-1. This unexpected inference is supported by the reconstructed spread of steppe vegetation and onset of loess formation in the Qilian Mountains between 13 and $11 \mathrm{ka}$, and the reconstruction of increasing runoff and the initial establishment of the terminal Zhuyeze Lake at the southern margin of the Gobi Desert during GS-1 (Küster et al., 2006; Mischke et al., 2016). The lower temperatures and reduced evaporation during GS-1 may have caused a more positive water balance of some of the desert lakes in the Gobi region already before the onset of the Holocene given that the inferred less brackish conditions did not result from local hydrological peculiarities in the catchment areas. However, detailed studies of the local late glacial conditions and the transition to the Holocene are required to assess the climatic significance of the GS-1 in Central Asia.

Lowest salinities in Lake Ulaan in the early Holocene and inferred wettest conditions were also reconstructed for the majority of climate records in ACA (Figure 5). Contrary inferences such as one based on dating of aeolian deposits in the Tian Shan Mountains by Long et al. (2017) exist and testify that available moisture may have varied significantly on a local scale, that the presence and accumulation of aeolian sands could have resulted from the higher activity of fluvial systems during wetter periods as suggested by Nottebaum et al. (2015), and/or that our understanding of geological processes in response to past climate change is at least partly far from sufficient. However, wettest conditions in the early Holocene in ACA derived from most available pollen-based records correspond also to wettest conditions inferred from the northeastern part of the Tibetan Plateau whilst only few similar inferences originate from more central or southern positions (Figure 5). In addition, wettest conditions in the early Holocene were suggested only for few records from East Asia. Thus, an assumed more northern penetration of the EASM and ISM during the early Holocene alone cannot fully explain the observed pattern. Instead, a more northern position of the westerlies jet earlier in the year and/or a less zonal and rather SW-NE alignment of the jet over Central Asia possibly existed in the early Holocene due to stronger summer insolation as proposed by Herzschuh et al. (2019). As a result, the prolongation of the monsoonal period possibly caused the higher moisture availability in the northeastern part of the Tibetan Plateau. Whether the EASM penetrated to central Mongolia or even farther to the west cannot be assessed based on the available data. Mostly dry or moderately wet conditions reconstructed for East Asian locations in the early Holocene probably resulted from the EASM which traversed the region relatively rapidly (Kong et al., 2017; Herzschuh et al., 2019). Decreasing moisture availability was recorded at Lake Ulaan soon after $10 \mathrm{ka}$. A dry and cool climate event was recorded in coastal East Asia and the western tropical Pacific at $9.8 \mathrm{ka}$ which possibly contributed to the climate deterioration in the catchment of Lake Ulaan after $10 \mathrm{ka}$ (Stott et al., 2004; Park et al., 2019).

The transition from wetter conditions during Zone 3 to drier conditions of Zone 4 at $9.4 \mathrm{ka}$ more or less coincides with the $9.2 \mathrm{ka}$ event widely recorded in the Mediterranean region and the Middle East (Magny et al., 2013; Dean et al., 2015; Flohr et al., 2016). Thus, the termination of the wettest and warmest Holocene conditions in central and southern Mongolia was possibly triggered by colder conditions and less incoming moisture delivered by the westerlies. However, the most significant reduction in the EASM and an abrupt sea surface temperature decrease in the western tropical Pacific was also recorded at $9.2 \mathrm{ka}$, and we cannot rule out that monsoonal precipitation had reached the catchment of Lake Ulaan during the wettest conditions in the early Holocene but not afterward anymore (Stott et al., 2004; Zhang et al., 2018).

Moderately wet conditions in the middle Holocene were inferred from the record of Lake Ulaan and were also reconstructed for the majority $(80 \%)$ of the records from ACA. Wettest conditions during the middle Holocene were proposed for about a third of the records from the Tibetan Plateau and half of the records from East Asia (Figure 5). The resulting moisture distribution pattern in the middle Holocene is consistent with a proposed southward-shifted, almost zonal alignment of the westerlies-jet-stream axis (Herzschuh et al., 2019). High monsoonal precipitation was apparently mostly confined to East Asia during the middle Holocene. 

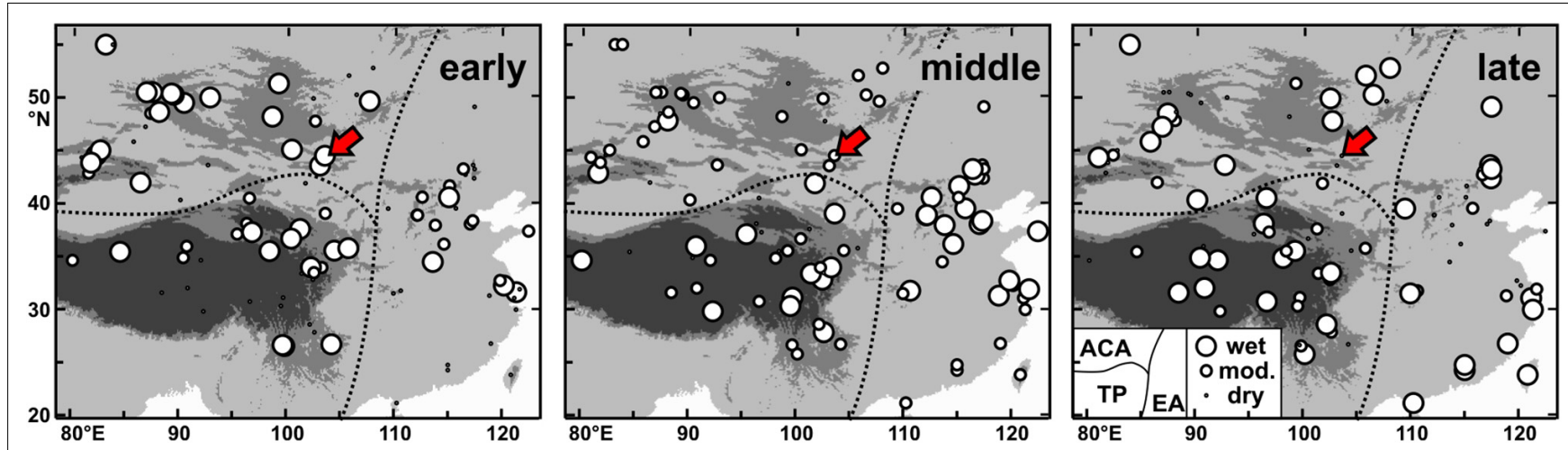

FIGURE 5 | Comparison of early, middle, and late Holocene moisture inferences (dry, moderate, or wet) for 101 records from arid Central Asia (ACA), the Tibetan Plateau (TP) and East Asia (EA). The majority (89) are pollen records examined by Herzschuh et al. (2019). In addition, 12 records from Bayan Tohomin Nuur (Felauer et al., 2012), Orog Nuur (Yu et al., 2019), Uigi Nuur (Wang et al., 2011), Hoton Nur (Rudaya and Li, 2013), the Nur Sphagnum Bog (Fukumoto et al., 2012), Wulungu Lake (Liu et al., 2008), the Yili Section (Li et al., 2011), the peat record BBP-13 (Xu et al., 2019), Kesang Cave (Cai et al., 2017), Zhuyeze Lake (Mischke et al., 2016), Lake Dali (Goldsmith et al., 2017), and this study (red arrow) are included.

The decline of Lake Ulaan's level and inferred dry climate conditions in its catchment in the late Holocene are supported by similar inferences from the nearby BTN and ON, and records from western Mongolia (Felauer et al., 2012; Yu et al., 2019; Figure 5). A series of closely spaced cold-dry events at 5.3, 4.7, $4.2,3.7,3.2,2.8$, and 2.4 ka was recorded in South Korea and the western tropical Pacific (Stott et al., 2004; Park et al., 2019). TOC concentrations and $\mathrm{C} / \mathrm{N}$ ratios of the Lake-Ulaan record show coinciding decreases at 5.3, 4.7, 3.2, and especially $2.8 \mathrm{ka}$, and possibly suggest that cold-dry spells in the late part of the middle and first third of the late Holocene in East Asia contributed to the observed lake-level lowering and drier conditions in Lake Ulaan's catchment in the late Holocene. More precise age data are clearly required to discuss the occurrence of such short-lived climate events in more detail. However, significant aridification was also observed in the eastern Mediterranean ca. 3.5-2.8 ka which was possibly conveyed to Central and East Asia by the westerlies jet (Schilman et al., 2001; Kaniewski et al., 2008; Magny et al., 2013; Kagan et al., 2015). In contrast to the inference of dry conditions at Lake Ulaan in the late Holocene, wettest climate conditions were reconstructed at about a third of the locations investigated in ACA (Figure 5). In addition, wettest climate conditions in the late Holocene were also inferred from a third of the records from the Tibetan Plateau and slightly more than a third $(38 \%)$ of the records in East Asia. The reconstructed moisture-distribution pattern in the late Holocene shows that locations where wettest Holocene conditions were reconstructed are more or less evenly spread over ACA, the Tibetan Plateau and East Asia. On a local scale, climate records where wettest and dry conditions were reconstructed occur more often next to each other in comparison to the early or middle Holocene. It could be argued that the insolation-driven later onset and shorter duration of the monsoon season and cooler conditions in the late Holocene caused not only less precipitation at higher latitudes but also reduced evaporation. Thus, the decrease of both precipitation and evaporation may have resulted in reduced effective moisture at one location if the former dominated or in higher effective moisture if the latter governed local conditions. Specific catchment conditions such as exposure of slopes, alignment of mountain ranges in relation to main wind directions, relative size of the upper reaches of a catchment, rock, soil, and vegetation types and related infiltration characteristics, extend of wetlands upstream or at the margins of a lake, etc., probably resulted in significant differences in effective moisture in neighboring regions. However, reconstructions based on proxy data and their assessment in comparison to results of atmospheric general circulation models are required to shed more light on the spatial distribution of effective moisture in the late Holocene in ACA, the Tibetan Plateau and East Asia.

\section{CONCLUSION}

Lee et al. $(2011,2013)$ had already suggested that the sediments of the ULB core mostly represent aeolian deposits. The reassessment of the available grain-size data and additional examination of the $180-250 \mu \mathrm{m}$ fraction showed that riverderived materials were accumulated predominantly during two different periods in Lake Ulaan. Silt-rich sediments which were accumulated ca. $16 \mathrm{ka}$ in the lake likely derived from high meltwater discharge to the lake, generated from melting glaciers in the uppermost reaches of the Ongin River in the southeastern Khangai Mountains. A second major pulse of fluvial sediments is recorded near the top of the core where increasing silt and sand fractions at the expense of clay-sized particles point to the approaching Ongin River mouth as a result of the shrinkage of Lake Ulaan in the late Holocene.

Our study shows that the lake waters were apparently too brackish for a flourishing ostracod population during GI-1 and that the salinity decreased in the GS-1. This result is surprising, given that cold and dry conditions are typically inferred for the period of GS-1 in Central Asia (Wang et al., 2010). Future studies will show whether the inferred rising lake levels during GS-1 mostly resulted from reduced evaporation and increasing 
moisture availability in the catchment or whether catchmentspecific peculiarities independent of regional climate conditions affected the lake. However, our study shows also that wettest conditions were established soon afterward in the catchment of Lake Ulaan, leading to more or less freshwater conditions in the lake in the early Holocene.

The fossil assemblage from Lake Ulaan suggests optimal, freshest conditions in the lake at ca. $10 \mathrm{ka}$ and a stepwise decline of the lake level starting soon afterward at $9.4 \mathrm{ka}$, and later in the middle and late Holocene at 6.8 and $3.2 \mathrm{ka}$. At least the former and latter lake-level drops where apparently triggered by global or at least regional aridification events.

Current occasional flooding of the modern playa probably contributes to freshwater discharge of the surficial local aquifer. However, the fossil record from the ULB core indicates that Lake Ulaan was mostly a brackish-water lake during the late glacial and Holocene, and that abundant freshwater resources beneath the ground cannot be expected in the region which was covered by the lake since ca. at least $17 \mathrm{ka}$.

Our study of the ULB core sediments cannot provide robust evidence for the assessment of proposed shorelines high above the current, dry lake floor (Sternberg and Paillou, 2015). Detailed, field-based mapping campaigns including the dating of shoreline features are required in addition to remote-sensing analysis to assess the extent and timing of Pleistocene or possibly even Holocene mega-lakes in this part of the Gobi Desert.

\section{REFERENCES}

Beck, L., Mendel, T., and Thindwa, J. (2007). The Enabling Environment for Social Accountability in Mongolia. Washington, DC: World Bank.

Buchan, G. D., Grewal, K. S., Claydon, J. J., and McPherson, R. J. (1993). A comparison of Sedigraph and Pipette methods for soil particle-size analysis. Aust. J. Soil Res. 31, 407-417.

Cai, Y., Chiang, J. C. H., Breitenbach, S. F. M., Tan, L., Cheng, H., Edwards, R. L., et al. (2017). Holocene moisture changes in western China, Central Asia, inferred from stalagmites. Quat. Sci. Rev. 158, 15-28. doi: 10.1016/j.quascirev. 2016.12.014

Chen, F., Yu, Z., Yang, M., Ito, E., Wang, S., Madsen, D. B., et al. (2008). Holocene moisture evolution in arid central Asia and its out-of-phase relationship with Asian monsoon history. Quat. Sci. Rev. 27, 351-364. doi: 10.1016/j.quascirev. 2007.10.017

Dean, J. R., Jones, M. D., Leng, M. J., Noble, S. R., Metcalfe, S. E., Sloane, H. J., et al. (2015). Eastern Mediterranean hydroclimate over the late glacial and Holocene, reconstructed from the sediments of Nar lake, central Turkey, using stable isotopes and carbonate mineralogy. Quat. Sci. Rev. 124, 162-174. doi: 10.1016/j.quascirev.2015.07.023

Dong, Z., Qian, G., Lv, P., and Hu, G. (2013). Investigation of the sand sea with the tallest dunes on Earth: China's Badain Jaran Sand Sea. Earth Sci. Rev. 120, 20-39. doi: 10.1016/j.earscirev.2013.02.003

Dulma, A. (1979). Hydrobiological outline of the Mongolian lakes. Int. Rev. Gesamten Hydrobiol. 64, 709-736. doi: 10.1002/iroh.19790640602

Felauer, T., Schlütz, F., Murad, W., Mischke, S., and Lehmkuhl, F. (2012). Late Quaternary climate and landscape evolution in arid Central Asia: a multiproxy study of lake archive Bayan Tohomin Nuur, Gobi desert, southern Mongolia. J. Asian Earth Sci. 48, 125-135. doi: 10.1016/j.jseaes.2011.12.002

Flohr, P., Fleitmann, D., Matthews, R., Matthews, W., and Black, S. (2016). Evidence of resilience to past climate change in Southwest Asia: early farming communities and the 9.2 and 8.2 ka events. Quat. Sci. Rev. 136, 23-39. doi: 10.1016/j.quascirev.2015.06.022

\section{DATA AVAILABILITY STATEMENT}

The raw data supporting the conclusions of this article will be made available by the authors, without undue reservation, to any qualified researcher.

\section{AUTHOR CONTRIBUTIONS}

YL designed the study. ML performed magnetic susceptibility measurements, treated sediment sub-samples for palaeontological analysis, and provided resulting sieve residues to $\mathrm{SM}$ who did the palaeontological analysis. SM wrote the original manuscript draft. All authors contributed to the revision of the text.

\section{FUNDING}

This work was partially supported by the Korea Polar Research Institute (Project PE20180).

\section{ACKNOWLEDGMENTS}

We thank LZ and HL who provided very constructive suggestions for the improvement of the original manuscript.

Fuhrmann, R. (2012). Atlas quartärer und rezenter Ostrakoden Mitteldeutschlands. Altenburger Naturwissenschaftliche Forschungen 15, $1-320$.

Fukumoto, Y., Kashima, K., Orkhonselenge, A., and Ganzorig, U. (2012). Holocene environmental changes in northern Mongolia inferred from diatom and pollen records of peat sediment. Quat. Int. 254, 83-91. doi: 10.1016/j.quaint.2011.10. 014

Ganbat, E., and Demberel, O. (2010). "Geologic background of the Hangay geothermal system, west-central Mongolia," in Proceedings of the World Geothermal Congress, Bali, 1-6.

Glöer, P., Boeters, H. D., and Pešić, V. (2014). Freshwater molluscs of Kyrgyzstan with description of one new genus and species (Mollusca: Gastropoda). Folia Malacol. 22, 73-81. doi: 10.12657/folmal.022.009

Glöer, P., and Pešić, V. (2007). Gyraulus meierbrooki, G. ioanis, and G. shasithree new Gyraulus spp. from the Skadar Lake Basin, Montenegro (Gastropoda: Planorbidae). Mollusca 25, 131-137.

Goldsmith, Y., Broecker, W. S., Xu, H., Polissar, P. J., de Menocal, P. B., Porat, N., et al. (2017). Northward extent of East Asian monsoon covaries with intensity on orbital and millennial timescales. Proc. Nat. Acad. Sci. U.S.A. 114, 1817-1821. doi: 10.1073/pnas.1616708114

Gunin, P. D., Vostokova, E. A., Dorofeyuk, N. I., Tarasov, P. E., and Black, C. C. (1999). Vegetation Dynamics of Mongolia. Dordrecht: Springer.

Hatfield, R. G., Woods, A., Lehmann, S. B., Weidhaas, N., Chen, C. Y., Kück, J., et al. (2020). Stratigraphic correlation and splice generation for sediments recovered from a large-lake drilling project: an example from Lake Junín. Peru. J. Paleolimnol. 63, 83-100. doi: 10.1007/s10933-019-00 098-w

Hem, J. D. (1982). "Conductance: a collective measure of dissolved ions," in Water Analysis, Inorganic Species, Vol. 1, Part 1, eds R. A. Minear and L. H. Keith (Cambridge, MA: Academic Press), 137-161. doi: 10.1016/b978-0-12-4983014.50009-8

Hempelmann, N. (2011). Aeolian Geomorphodynamics in Endorheic Basins of the Mongolian Gobi Desert. Ph.D. thesis, University Mainz, Mainz. 
Herzschuh, U., Cao, X., Laepple, T., Dallmeyer, A., Telford, R. J., Ni, J., et al. (2019). Position and orientation of the westerly jet determined Holocene rainfall patterns in China. Nat. Commun. 10:2376.

Holguín, L. R., and Sternberg, T. (2018). A GIS based approach to Holocene hydrology and social connectivity in the Gobi Desert. Mongolia. Archaeol. Res. Asia 15, 137-145. doi: 10.1016/j.ara.2016.12.001

Jaeckel, S. G. A. (1962). "Ergänzungen und Berichtigungen zum rezenten und quartären Vorkommen der mitteleuropäischen Mollusken," in Die Tierwelt Mitteleuropas, 2: Weichtiere - Mollusca, eds P. Brohmer, P. Ehrmann, and P. Ulmer (Leipzig: Quelle \& Meyer), 225-294.

Janz, H. (1994). Zur Bedeutung des Schalenmerkmals, Marginalrippen' der Gattung Ilyocypris (Ostracoda, Crustacea). Stuttgarter Beiträge zur Naturkunde Ser. B 206, 1-19.

Jia, J., Bai, J., Wang, W., Zhang, G., Wang, X., Zhao, Q., et al. (2018). Changes of biogenic elements in Phragmites australis and Suaeda salsa from salt marshes in Yellow River Delta, China. Chin. Geogr. Sci. 28, 411-419. doi: 10.1007/s11769018-0959-1

Kagan, E. J., Langgut, D., Boaretto, E., Neumann, F. H., and Stein, M. (2015). Dead Sea levels during the Bronze and Iron ages. Radiocarbon 57, 237-252. doi: 10.2458/azu_rc.57.18560

Kaniewski, D., Paulissen, E., van Campo, E., Al-Maqdissi, M., Bretschneider, J., and Van Lerberghe, K. (2008). Middle East coastal ecosystem response to middleto-Late-Holocene abrupt climate changes. Proc. Natl. Acad. Sci. U.S.A. 105, 13941-13946. doi: 10.1073/pnas.0803533105

Kong, W., Swenson, L. M., and Chiang, J. C. H. (2017). Seasonal transitions and the westerly jet in the Holocene East Asian summer monsoon. J. Clim. 30, 3343-3365. doi: 10.1175/jcli-d-16-0087.1

Küster, Y., Hetzel, R., Krbetschek, M., and Tao, M. (2006). Holocene loess sedimentation along the Qilian Shan (China): Significance for understanding the processes and timing of loess deposition. Quat. Sci. Rev. 25, 114-125. doi: 10.1016/j.quascirev.2005.03.003

Lee, M. K., Lee, Y. I., Lim, H. S., Lee, J. I., Choi, J. H., and Yoon, H. I. (2011). Comparison of radiocarbon and OSL dating methods for a Late Quaternary sediment core from Lake Ulaan, Mongolia. J. Paleolimnol. 45, 127-135. doi: 10.1007/s10933-010-9484-7

Lee, M. K., Lee, Y. I., Lim, H. S., Lee, J. I., and Yoon, H. I. (2013). Late PleistoceneHolocene records from Lake Ulaan, Southern Mongolia: implications for east Asian palaeomonsoonal climate changes. J. Quat. Sci. 28, 370-378. doi: 10.1002/ jqs. 2626

Lehmkuhl, F., Grunert, J., Hülle, D., Batkhishig, O., and Stauch, G. (2018). Paleolakes in the Gobi region of southern Mongolia. Quat. Sci. Rev. 179, 1-23. doi: 10.1016/j.quascirev.2017.10.035

Li, X., Zhao, K., Dodson, J., and Zhou, X. (2011). Moisture dynamics in central Asia for the last 15 kyr: new evidence from Yili Valley, Xinjiang, NW China. Quat. Sci. Rev. 30, 3457-3466. doi: 10.1016/j.quascirev.2011.09.010

Li, Z., Wei, Z., Dong, S., and Chen, Q. (2018). The paleoenvironmental significance of spatial distributions of grain size in groundwater-recharged lakes: a case study in the hinterland of the Badain Jaran Desert, northwest China. Earth Surf. Process. Landforms 43, 363-372. doi: 10.1002/esp.4248

Liu, X., Herzschuh, U., Shen, J., Jiang, Q., and Xiao, X. (2008). Holocene environmental and climatic changes inferred from Wulungu Lake in northern Xinjiang, China. Quat. Res. 70, 412-425. doi: 10.1016/j.yqres.2008. 06.005

Liu, Y., Jiang, M., Lu, X., Zhang, Z., and Lou, Y. (2015). Leaf carbon, nitrogen and phosphorus stoichiometry of Phragmites australis in northeastern China. Fresenius Env. Bull. 24, 4711-4719.

Long, H., Shen, J., Chen, J., Tsukamoto, S., Yang, L., Cheng, H., et al. (2017). Holocene moisture variations over the semiarid-arid central Asia revealed by a comprehensive sand-dune record from the central Tian Shan, NW China. Quat. Sci. Rev. 174, 13-32. doi: 10.1016/j.quascirev.2017.08.024

Lowe, J. J., Rasmussen, S. O., Björck, S., Hoek, W. Z., Steffensen, J. P., Walker, M. J. C., et al. (2008). Synchronisation of palaeoenvironmental events in the North Atlantic region during the Last Termination: a revised protocol recommended by the INTIMATE group. Quat. Sci. Rev. 27, 6-17. doi: 10.1016/ j.quascirev.2007.09.016

Magno, M. C., Venti, F., Gaglianone, G., Pierfranceschi, G., and Romano, E. (2017). "Grain size analysis: a comparison between laser granulometer and sedigraph," in Proceedings of the IMEKO Int. Conf. Metrology for the Sea, Naples, 210-214.
Magny, M., Combourieu Nebout, N., De Beaulieu, J. L., Bout-Roumazeilles, V., Colombaroli, D., Desprat, S., et al. (2013). North-south palaeohydrological contrasts in the central Mediterranean during the Holocene: tentative synthesis and working hypotheses. Clim. Past. 9, 2043-2071. doi: 10.5194/cp-9-20432013

Meisch, C. (2000). Freshwater Ostracoda of Western and Central Europe. Heidelberg: Spektrum.

Miehe, G., Schlütz, F., Miehe, S., Opgenoorth, L., Cermak, J., Samiya, R., et al. (2007). Mountain forest islands and Holocene environmental changes in Central Asia: a case study from the southern Gobi Altay, Mongolia. Palaeogeogr. Palaeoclimatol. Palaeoecol. 250, 150-166. doi: 10.1016/j.palaeo.2007.03.022

Mischke, S., Almogi-Labin, A., Al-Saqarat, B., Rosenfeld, A., Elyashiv, H., Boomer, I., et al. (2014). An expanded ostracod-based conductivity transfer function for climate reconstruction in the Levant. Quat. Sci. Rev. 93, 91-105. doi: 10.1016/j. quascirev.2014.04.004

Mischke, S., Fuchs, D., Riedel, F., and Schudack, M. E. (2002). Mid to Late Holocene palaeoenvironment of Lake Eastern Juyanze (north-western China) based on ostracods and stable isotopes. Geobios 35, 99-110. doi: 10.1016/s0016-6995(02) 00013-x

Mischke, S., Herzschuh, U., Massmann, G., and Zhang, C. (2007). An ostracodconductivity transfer-function for Tibetan lakes. J. Paleolimnol. 38, 509-524. doi: 10.1007/s10933-006-9087-5

Mischke, S., Lai, Z., Long, H., and Tian, F. (2016). Holocene climate and landscape change in the northeastern Tibetan Plateau foreland inferred from the Zhuyeze Lake record. Holocene 26, 643-654. doi: 10.1177/0959683615612570

Müller, H.-W., Dohrmann, R., Klosa, D., Rehder, S., and Eckelmann, W. (2009). Comparison of two procedures for particle-size analysis: köhn pipette and X-ray granulometry. J. Plant Nutr. Soi Sci. 172, 172-179. doi: 10.1002/jpln.200800065

Murad, W. (2011). Late Quaternary Vegetation History and Climate Change in the Gobi Desert, South Mongolia. Ph.D. thesis, Georg-August-Universität Göttingen, Göttingen.

Nottebaum, V., Lehmkuhl, F., Stauch, G., Lu, H., and Yi, S. (2015). Late Quaternary aeolian sand deposition sustained by fluvial reworking and sediment supply in the Hexi Corridor - An example from northern Chinese drylands. Geomorphology 250, 113-127. doi: 10.1016/j.geomorph.2015.08.014

Orkhonselenge, A., Komatsu, G., and Uuganzaya, M. (2018). Middle to late Holocene sedimentation dynamics and paleoclimate conditions in the Lake Ulaan basin, southern Mongolia. Géomorphologie 24, 351-363. doi: 10.4000/ geomorphologie. 12219

Park, J., Park, J., Yi, S., Cheul Kim, J., Lee, E., and Choi, J. (2019). Abrupt Holocene climate shifts in coastal East Asia, including the $8.2 \mathrm{ka}, 4.2 \mathrm{ka}$, and $2.8 \mathrm{ka} \mathrm{BP}$ events, and societal responses on the Korean peninsula. Sci. Rep. 9:10806.

Pötsch, S., Rother, H., Lorenz, S., Walther, M., and Lehmkuhl, F. (2015). Timing of late Pleistocene glaciation in Mongolia: surface exposure dating reveals a differentiated pattern of glacial forcing. Geophys. Res. Abstr. 17:EGU2015-4815.

Romanov, R. E., Zhakova, L. V., Bazarova, B. B., and Kipriyanova, L. M. (2014). The charophytes (Charales, Charophyceae) of Mongolia: a checklist and synopsis of localities, including new records. Nova Hedwigia 98, 127-150. doi: 10.1127/ 0029-5035/2013/0134

Rother, H., Lehmkuhl, F., Fink, D., and Nottebaum, V. (2014). Surface exposure dating reveals MIS-3 glacial maximum in the Khangai Mountains of Mongolia. Quat. Res. 82, 297-308. doi: 10.1016/j.yqres.2014.04.006

Rudaya, N., and Li, H.-C. (2013). A new approach for reconstruction of the Holocene climate in the Mongolian Altai: the high-resolution $\delta^{13} \mathrm{C}$ records of TOC and pollen complexes in Hoton-Nur Lake sediments. J. Asian Earth Sci. 69, 185-195. doi: 10.1016/j.jseaes.2012.12.002

Schilman, B., Bar-Matthews, M., Almogi-Labin, A., and Luz, B. (2001). Global climate instability reflected by eastern Mediterranean marine records during the late Holocene. Palaeogeogr. Palaeoclimatol. Palaeoecol. 176, 157-176. doi: 10.1016/s0031-0182(01)00336-4

Shvartsev, S., Kolpakova, M. N., Isupov, V. P., Vladimirov, A. G., and Ariunbileg, S. (2014). Geochemistry and chemical evolution of saline lakes of Western Mongolia. Geochem. Int. 52, 388-403. doi: 10.1134/s0016702914030070

Sternberg, T., and Paillou, P. (2015). Mapping potential shallow groundwater in the Gobi Desert using remote sensing: Lake Ulaan Nuur. J. Arid Env. 118, 21-27. doi: 10.1016/j.jaridenv.2015.02.020

Stott, L., Cannariato, K., Thunell, R., Haug, G. H., Koutavas, A., and Lund, S. (2004). Decline of surface temperature and salinity in the western tropical 
Pacific Ocean in the Holocene epoch. Nature 431, 56-59. doi: 10.1038/ nature02903

Suzuki, Y. (2013). "Conflict between mining development and nomadism in Mongolia," in The Mongolian Ecosystem Network, eds N. Yamamura, N. Fujita, and A. Maekawa (Cham: Springer), 269-294. doi: 10.1007/978-4-431-540526_20

Tserensodnom, J. (1971). Lakes of Mongolia. Ulaanbaatar: State Publishing.

Tserensodnom, J. (2000). A Catalog of Lakes in Mongolia. Ulaanbaatar: Shuvuum Saaral Publishing.

Umbanhowar, C. E., Shinneman, A. L. C., Tserenkhand, G., Hammon, E. R., Lor, P., and Nail, K. (2009). Regional fire history based on charcoal analysis of sediments from nine lakes in western Mongolia. Holocene 19, 611-624. doi: $10.1177 / 0959683609104039$

Van der Meeren, T., Mischke, S., Sunjidmaa, N., Herzschuh, U., Ito, E., Martens, K., et al. (2012). Subfossil ostracode assemblages from Mongolia - Quantifying response for paleolimnological applications. Ecol. Indic. 14, 138-151. doi: 10. 1016/j.ecolind.2011.07.004

van Harten, D. (1979). "Some new shell characters to diagnose the species of the Ilyocypris gibba - biplicata - bradyi group and their ecological significance," in Taxonomy, Biostratigraphy and Distribution of Ostracodes, Proceedings of the 7th International Symposium on Ostracodes, (Belgrade: Serbian Geological Society), 71-76.

Vinarski, M. V., Palatov, D. M., and Marinskiy, V. V. (2017). Checklist of the freshwater snails (Mollusca: Gastropoda) of Mongolia. Zootaxa 4317, 45-78.

Wang, W., Ma, Y., Feng, Z., Narantsetseg, T., Liu, K.-B., and Zhai, X. (2011). A prolonged dry mid-Holocene climate revealed by pollen and diatom records from Lake Ugii Nuur in central Mongolia. Quat. Int. 229, 74-83. doi: 10.1016/ j.quaint.2010.06.005

Wang, Y., Liu, X., and Herzschuh, U. (2010). Asynchronous evolution of the Indian and East Asian Summer Monsoon indicated by Holocene moisture patterns in monsoonal central Asia. Earth Sci. Rev. 103, 135-153. doi: 10.1016/j.earscirev. 2010.09.004

Winter, U., and Kirst, G. O. (1990). Salinity response of a freshwater charophyte, Chara vulgaris. Plant Cell Env. 13, 123-134. doi: 10.1111/j.1365-3040.1990. tb01284.x

Xu, H., Zhou, K., Lan, J., Zhang, G., and Zhou, X. (2019). Arid Central Asia saw mid-Holocene drought. Geology 47, 255-258. doi: 10.1130/g45686.1

Yu, K., Lehmkuhl, F., Diekmann, B., Zeeden, C., Nottebaum, V., and Stauch, G. (2017). Geochemical imprints of coupled paleoenvironmental and provenance change in the lacustrine sequence of Orog Nuur, Gobi Desert of Mongolia. J. Paleolimnol. 58, 511-532. doi: 10.1007/s10933-017-0007-7

Yu, K., Lehmkuhl, F., Schlütz, F., Diekmann, B., Mischke, S., Grunert, J., et al. (2019). Late Quaternary environments in the Gobi Desert of Mongolia: vegetation, hydrological, and palaeoclimate evolution. Palaeogeogr. Palaeoclimatol. Palaeoecol. 514, 77-91. doi: 10.1016/j.palaeo.2018. 10.004

Zhang, W., Yan, H., Dodson, J., Cheng, P., Liu, C., Li, J., et al. (2018). The 9.2 ka event in Asian summer monsoon area: the strongest millennial scale collapse of the monsoon during the Holocene. Clim. Dyn. 50, 2767-2782. doi: 10.1007/ s00382-017-3770-2

Conflict of Interest: The authors declare that the research was conducted in the absence of any commercial or financial relationships that could be construed as a potential conflict of interest.

Copyright (c) 2020 Mischke, Lee and Lee. This is an open-access article distributed under the terms of the Creative Commons Attribution License (CC BY). The use, distribution or reproduction in other forums is permitted, provided the original author(s) and the copyright owner(s) are credited and that the original publication in this journal is cited, in accordance with accepted academic practice. No use, distribution or reproduction is permitted which does not comply with these terms. 